\title{
Sickle Cell Anemia with Megaloblastic Crisis: Deficiency or Demand?
}

\author{
${ }^{1}$ Sourya Acharya, ${ }^{2}$ Samarth Shukla, ${ }^{3}$ Ajinkya Jamthe, ${ }^{4}$ Ankita Tamhane
}

\begin{abstract}
Megaloblastic erythropoiesis has been associated with hemolytic anemias. Sickle cell disease (SCD) presenting as megaloblastosis is a rare phenomenon. We present a case of sickle cell anemia presenting with painful crisis along with megaloblastic blood picture.

Keywords: Anemia, Erythropoiesis, Megaloblastosis, Sickle cell disease.
\end{abstract}

How to cite this article: Acharya S, Shukla S, Jamthe A, Tamhane A. Sickle Cell Anemia with Megaloblastic Crisis: Deficiency or Demand? World J Anemia 2017;1(2):63-64.

\section{Source of support: Nil}

Conflict of interest: None

\section{INTRODUCTION}

Sickle cell disease usually presents with vaso-occlusive, aplastic, hyperhemolytic, splenic sequestration, and acute chest syndrome as predominant crisis. Though megaloblastic crisis is a known phenomenon in thalassemia and hereditary spherocytosis, ${ }^{1-4} \mathrm{SCD}$ with megaloblastic crisis is rare. The possible explanation may be the nutritional deficiency of folate and vitamin B12.

\section{CASE REPORT}

A34-year-old male, a diagnosed case of SCD since 18 years, presented to us with complaints of bone pains, myalgia, and fever of 3 days duration. On examination, pallor was present, icterus was positive, jugular venous pressure was normal, and there was no edema feet. Mild glossitis was present on tongue. Systemic examination was normal. Neurologic examination was normal. Patient

\footnotetext{
${ }^{1,2}$ Professor, ${ }^{3}$ Resident, ${ }^{4}$ Assistant Professor

${ }^{1,3}$ Department of Medicine, Jawaharlal Nehru Medical College, Datta Meghe Institute of Medical Sciences, Wardha Maharashtra, India

${ }^{2,4}$ Department of Pathology, Jawaharlal Nehru Medical College, Datta Meghe Institute of Medical Sciences, Wardha Maharashtra, India

Corresponding Author: Sourya Acharya, Professor, Department of Medicine, Jawaharlal Nehru Medical College, Datta Meghe Institute of Medical Sciences, Wardha, Maharashtra, India Phone: +919371454269, e-mail: souryaacharya74@gmail.com
}

was diagnosed as a case of SCD since 18 years by hemoglobin $(\mathrm{Hb})$ electrophoresis, which showed SS pattern. Episodes of crisis were eight in number, which required hospitalization in the past 18 years. This was the ninth hospital admission with painful crisis. Patient was taking intermittent folic acid and zinc supplementation. He was a pure vegan.

Investigation revealed $\mathrm{Hb} 7.8 \mathrm{gm} \%$, total leukocyte count 14,000 with neutrophilic leukocytosis, mean cell volume (MCV) $118 \mathrm{fL}$. Reticulocyte count was 3.2\%, and repeat $\mathrm{Hb}$ electrophoresis revealed SS pattern. Serum lactate dehydrogenase was $850 \mathrm{U}$ (normal range 140-280 $\mathrm{U} / \mathrm{L}$ ). Total serum bilirubin was $3.8 \mathrm{mg} \%$, out of which unconjugated was $2.8 \mathrm{mg} \%$ and conjugated was 1.0 $\mathrm{mg} \%$. Serum folate level was $3.2 \mathrm{nmol} / \mathrm{L}$ (normal range $4.5-45.3 \mathrm{nmol} / \mathrm{L}$ ). Serum cobalamin level was $126 \mathrm{ng} / \mathrm{L}$ (normal range 180-914 ng/L). Cultures of blood and urine were negative. Further testing uncovered very high plasma methylmalonic acid $(1640 \mathrm{nmol} / \mathrm{L})$, homocysteine $(135.9 \mu \mathrm{mol} / \mathrm{L})$. Serum antibodies to intrinsic factor was negative.

Patient was treated with antibiotics, analgesics, injection vitamin B12 $1000 \mu \mathrm{g}$ intramuscularly for 7 days and folic acid $5 \mathrm{mg}$ postoperative once a day. Repeat peripheral smear after 5 days showed normocytic red blood cells (RBCs) suggesting response to vitamin B12 and folate therapy (Fig. 1). Hemoglobin after 1 week was $9 \mathrm{gm} \%$ and $\mathrm{MCV}$ was $98 \mathrm{fL}$. Patient was discharged on folic acid $5 \mathrm{mg}$

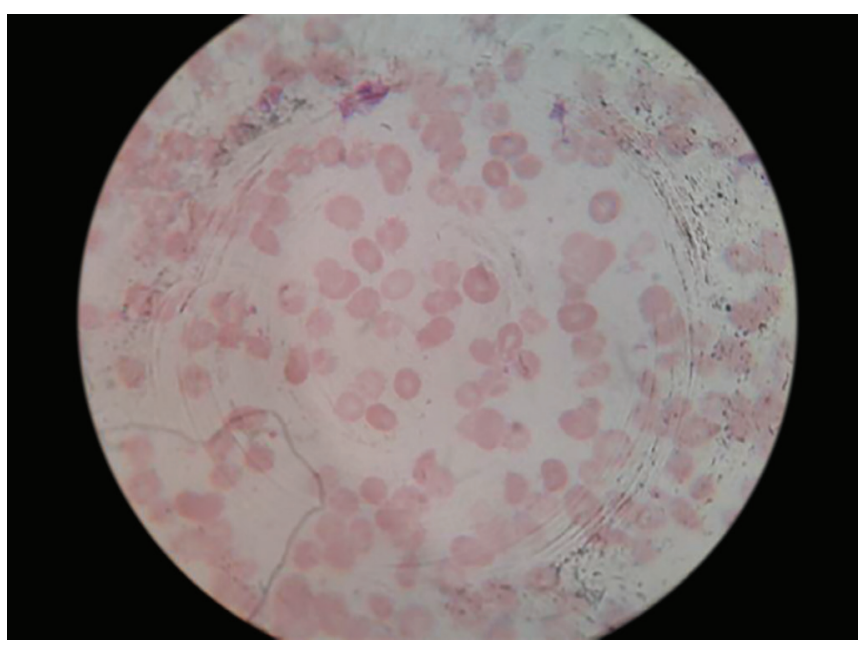

Fig. 1: Peripheral smear showing macrocytic RBCs with mild anisopoikilocytosis 
once a day to be continued, injection vitamin B12 $1000 \mu \mathrm{g}$ once a month to continue, and zinc supplementation.

\section{DISCUSSION}

The occurrence of megaloblastic blood picture in sickle cell anemia primarily raises two basic questions: the first question is whether the megaloblastic anemia in this case is due to deficiency of isolated folic acid or vitamin B12 or both. The second question is whether there is an etiological relationship between SCD and megaloblastosis or it is a coincidental finding. The second question is a rare assumption because hemolytic anemias unlikely present with macrocytosis unless the patient has autoantibodies against intrinsic factor or against islet cells. Literature shows that many of the patients have normal B12 levels, suggesting that the actual culprit is folate deficiency. ${ }^{5,6}$ Unlike the above scenario, our patient had vitamin B12 deficiency also. We ruled out pernicious anemia with negative antibody screening. ${ }^{7}$ The cause of cobalamin deficiency in our case was dietary deficiency, as the patient was a pure vegan.

Another school of thought argues that folic acid and other hematopoietic factors are required in increased amount at times of increased erythropoiesis. Whenever sickle cell crisis is associated with hyperhemolysis, the demand of increased erythropoiesis consumes more folate, leading to a relative folate deficiency and megaloblastosis. ${ }^{8}$

\section{REFERENCES}

1. Reisner EH Jr. The nature and significance of megaloblastic blood formation. Blood 1958 Apr;13(4):313-338.

2. Grunland S. Megaloblastic hemolytic anemia. Act Med Scand 1950;138(Suppl 239):101.

3. Leibetseder F. Die Erythropoese beim Hamolytischen Icterus. Sang 1950;21:155.

4. Schlagetter K. Die Bedentung der Knockenmarksuntersuchung fur die Diagnose der Anamien in der Ge-burtshilfe. Arch Gynakol 1955;185:641.

5. Girdwood RH. The megaloblastic anaemias. Quart J Med 1956;25:87.

6. Mollin DL, Ross GIM. Vitamin B12 deficiency in the megaloblastic anaemias. Proc R Soc Med 1954 Jun;47(6):428-431.

7. Sinow RM, Johnson CS, Karnaze DS, Siegel ME, Carmel R. Unsuspected pernicious anemia in a patient with sickle cell disease receiving routine folate supplementation. Arch Intern Med 1987 Oct;147(10):1828-1829.

8. Westerman MP, Bacus JW. Red blood cell morphology in sickle cell anemia as determined by image processing analysis: the relationship to painful crises. Am J Clin Pathol 1983 Jun;79(6):667-672. 